\title{
The Effect of Internal Marketing on Competitive Advantage as Organizational Coaching - The Mediating Effect of Service Innovation
}

\author{
Misook Yeum ${ }^{1}$, Kukhoan Wee ${ }^{2}$ and Wonseok Bang ${ }^{3}$ \\ ${ }^{1}$ Lifelong Center at Korea Human Resources Bank, 138 Bumil-ro, Pusanjin-gu, \\ Pusan, South Korea \\ ${ }^{2}$ Department of Convergence Wellness at Sungduk University, 1135-5, Hwannam- \\ ri, Sinnyeong-myeon, Yeongcheon-city, Gyeongsangbuk-do, South Korea \\ ${ }^{3}$ Business Department at Gyeongnam National University, 150-1, Chiram-dong, \\ Jinju-si, Gyeongsangnam-do, South Korea \\ Corresponding Author: bangws@daum.net
}

\begin{abstract}
This study aims to examine the relationship between internal marketing and competitive advantage in the organizational coaching approach to gain competitive advantage in Korea. We construct the sub-elements of internal marketing that are communication, compensation, and empowerment, and identify the relationships among internal marketing, service innovation and competitive advantage. To accomplish the purpose of this study, we conducted a questionnaire survey of 220 employees working in three branches of the Korea Health Care Association and collected the data and verified the hypotheses through SPSS and AMOS analysis. As a result, internal marketing has a significant positive influence on service innovation and directly affect competitive advantage as organizational coaching. However, the effect of internal marketing on service innovation did not support. In other words, there is no mediating effect of service innovation on the relationship between internal marketing and competitive advantage. These results suggest that internal marketing enhances competitive advantage as a role of organizational coaching. Therefore, this paper suggests practical implications for public hospital managers, including private hospital managers, from a management perspective.
\end{abstract}

Keywords: Internal marketing, service innovation, competitive advantage, organizational coaching 


\section{Introduction}

With a rapidly changing competitive environment, any organization including hospitals faces various problems to solve. One of the important problems is of how to enhance the competitive advantage. That is why organizational leader and manager have worked hard to reach the goal of sustainable competitive advantage.

One of the solutions of this problem is the internal marketing that influences the employee attitude and changes the process of service with a new idea, in turn, lead to competitive advantage. According to survey results in the past few years, even though customers have paid more attention to healthy ratios (Distanont, and O. Khongmalai, 2018) and pay attention to keeping good health, increase in hospitals supporting many diverse and convenient service is drawing fierce in competition. In these keen competitions, all organization including even non-profit organization has attempted to gain a competitive advantage.

One of the solutions to this problem, internal elements of an organization must be focused. Namely, an organization must focus on internal customers to be satisfied.

It is no possibility to satisfy external customers unless the internal customer insider an organization are satisfied to improve the organization's competitiveness. As a way of satisfying internal customers, managers in an organizational layout job design and welfare for satisfying internal customer needs, and employ internal marketing to motivate and generate performance while recruiting qualified external talent.

Sub-dimensions of internal marketing as an organization coaching such as communication, rewards are very essential element to competitive advantage.

Meanwhile, actually, innovation and creative ideas come from factors inside and outside an organization (Chen et al., 2006, Wei Chong et al., 2011). This paper focused on the internal view of the organization as an organization coaching. Therefore, we suggested that internal marketing is an important variable that gains a sustainable competitive advantage. We emphasized on the aspects of internal marketing as organizational coaching and innovation that lead to competitive advantages in the hospital industry.

We aim to identify internal marketing according to the three sub-dimensions (direction, development, relationship) and the relationship between internal marketing and service innovation and competitive advantage, achieving several theoretical and managerial contributions.

\section{Literature Review}

Internal marketing. Internal marketing is carried out only through coaching of the leader, who establishes a relationship that sets the direction, sets goals, and shares vison with internal customers in an organization. Besides, a leader's coaching 
enhanced the organization's ability through clear performance compensation and other positive coaching skills.

Papadas et al. (2018) proposed that internal green marketing has an effect on the relationships between strategic and competitive advantage as a moderator, in turn, it is important factor in reaching a competitive advantage in the fierce competitive market. On the other hand, a study on creating competitive advantage through internal marketing in the medical industry, internal marketing is the antecedent of self-efficacy, self-esteem, employee satisfaction, commitment and service innovation, and self-efficacy influences on worker's job performance (Bang, 2017; Choi, 2018).

In the study on relationships between internal marketing factors on technological innovation and perceived service quality in telecommunications, Jung et al. (2015) demonstrated that internal marketing factors - the support of executives, empowerment, internal communication, and education and traininginfluence process innovation. Furthermore, Bang et al. (2017) mentioned that internal communication, training \& education among internal marketing factors motivated employees toward service attitude and enhancement of service quality such as reliability.

Moreover, internal marketing influences some positive effects on organizational internal performance and external performance to gain a competitive advantage. For instance, Woi and Lee (2009) proposed that the differentiation strategy and cost advantage strategy of hotel companies have a mediating effect on the effect of internal marketing on the balance performance between financial performance and non-financial performance. Further, Shim and Choi (2014) proved that internal marketing is associated with job satisfaction, customer orientation and organizational performance. Based on this result, they suggested that managers or CEOs must make an effort to enhance competitiveness through internal marketing.

Meanwhile, Ieong and Lam (2016) offered five sub-elements of internal marketing, following elements: vision, overall development, communication, job training, and reward system. Through consideration of these previous studies, we employed three elements of internal marketing: communication, empowerment, reward.

Service innovation. Researchers defined service innovation differently and broadly according to purpose of study. In the broad meaning of service innovation including close stakeholders, Hsieh et al. (2014) defined service innovation as "creating value for customers, employees, business owners, alliance partners, and communities through new and/or improved service offerings, service processes, and service business models". In a narrow meaning of service innovation-regarding only an organization-, service innovation is as an organization's process of developing new system, or creating new value through human resource and information 
integration (Skalen et al., 2015). Hence, as an organization adopts service innovation by using various information and resources to provide a service that a customer wants, satisfaction with the service of the customer increases and customer loyalty increases. In this regard, service innovation provides a vital effective factor to drive new service development and improve existing services, gain in turn the competitive advantage.

Competitive advantage. Competitive advantage has been defined as "the quality that brings about success" and the firm's ability to create superior value for its customers who want to meet their needs, offering lower prices than competitors for equivalent benefits or providing unique benefits that more than offset a higher price, and providing higher customers value than customers expectation (Poter, and Millar, 1985). To create a competitive advantage, a company's management resources or core competencies must be unique and not possessed by a competitor and must be consistent with the success factors in the industry. Recently, the diversity of organization also is one of the competitive advantage factors (Kim, 2018).

Based on Porter's concept, corporate competitive advantage determines how to provide an organization's intrinsic value to customers, which means differentiation from competitors and superiority of product or service selection from customers and provides higher customer value than customers' expectations or their competitors.

Based on the previous studies, we set the hypotheses are listed as follows:

H1: Internal marketing influences positively service innovation.

$\mathrm{H} 2$ : Service innovation influences positively competitive advantage.

H3: Internal marketing influences positively competitive advantage.

\section{Methodology}

Conceptual model. This paper is to investigate the relationships among IM, that consist of communication, reward, empowerment, service innovation and competitive advantage for the hospital organization. The conceptual model is shown in Fig 1.

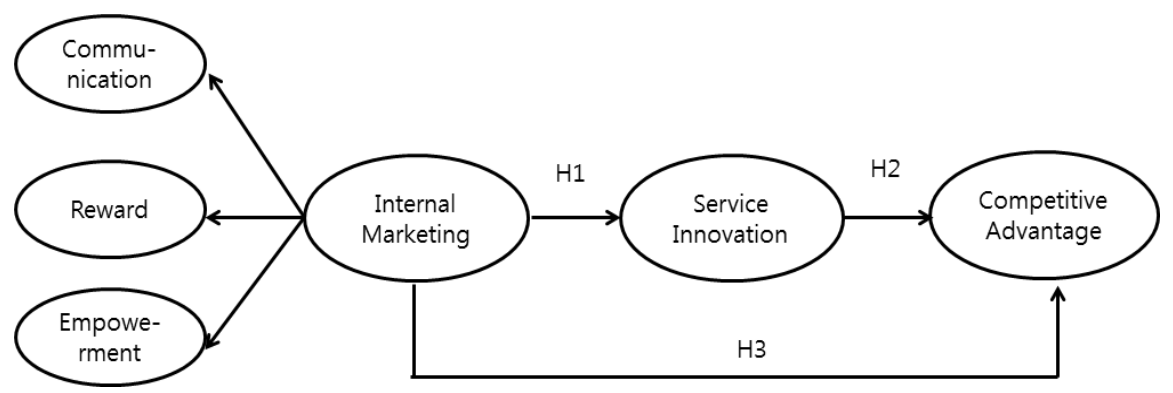

Fig. 1: Conceptual model. 
Samples. A survey for some healthcare centers in Gyeongnam province in Korea was conducted to collect data. When sending out the 220 questionnaires, we apply a cross test and random order items to avoid common method biases. Altogether, we get 214 respondents. We delete 15 invalid replies and get 199 valid respondents at the end.

\section{Results}

Result of confirmatory analysis. The measurement items of this study, confirmatory factor analysis was performed for each component of the construct, and items that inhibited a single dimension were removed. The goodness-of-fit of the model was assessed to derive the optimal state of the item composition. RMSEA (root mean square error of approximation: preferably 0.08 or less), NFI (Normed Fit Index: 0.9 or more is preferable), $\mathrm{x}^{2}$ (smaller is preferable), $\mathrm{p}$-value for $\mathrm{x}^{2}$ (preferably 0.05 or more) is used (Gefen et al., 2001). Further, reliability (Cronbach's a) of each construct is more than 0.6, composite reliability of all indicators were above thresholds, which exceeds the acceptable level suggested by Murphy and Davidshofer (1988) and by Nunnally and Bernstin (1994).

Table 1 presented the CFA results. AMOS 21.0 was used for the analysis of the measurement model. Goodness of fit was $\chi^{2} / \mathrm{df}=275.528(142), \quad \mathrm{p}=0.000$, $\mathrm{CMIN} / \mathrm{DF}=1.940, \mathrm{GFI}=0.881, \mathrm{IFI}=0.962, \mathrm{TLI}=0.954, \mathrm{CFI}=0.962, \mathrm{RMSEA}=0.075$ as shown in Table 1 . GFI is 0.881 , which is somewhat insufficient, which is not enough to satisfy all the goodness of fit of the index. Considering the remaining goodness-of-fit index and overall matters, it was judged that the statistical analysis was adequate. Cronbach's $\alpha$ value of each variable is 0.888 or more and the CR values are over 0.932 . The dispersion extraction index was higher than 0.719 . Therefore, reliability and concentration validity was ensured.

So, all factor loadings were statistically significant and reliabilities were above 0.7. The average variation extracted (AVE) values for all constructs were above 0.5. The results of CFA supported discriminant validity due to all indicators fitted. The CFA model indicated a good fit to data. The CFA results are presented in Table 1.

Table. 1: Results of confirmatory factor analyses

\begin{tabular}{|c|c|c|c|c|c|c|c|}
\hline Variables & Items & Estimates & SE & $\begin{array}{c}\text { T } \\
\text { value }\end{array}$ & Cronbach' $\alpha$ & CR & AVE \\
\hline \multirow{5}{*}{ Communication } & $\mathrm{X} 1$ & 0.873 & - & - & & & \\
\cline { 2 - 6 } & $\mathrm{X} 2$ & 0.841 & 0.057 & 15.834 & \multirow{2}{*}{0.910} & \multirow{2}{*}{0.911} & \multirow{2}{*}{0.719} \\
\cline { 2 - 8 } & $\mathrm{X} 3$ & 0.804 & 0.063 & 14.608 & & & \\
\cline { 2 - 8 } & $\mathrm{X} 4$ & 0.873 & 0.062 & 16.930 & & & \\
\hline
\end{tabular}




\begin{tabular}{|c|c|c|c|c|c|c|c|}
\hline \multirow{5}{*}{ Reward } & X6 & 0.843 & 0.066 & 15.403 & \multirow{5}{*}{0.926} & \multirow{5}{*}{0.857} & \multirow{5}{*}{0.735} \\
\hline & $\mathrm{X} 7$ & 0.876 & 0.063 & 16.500 & & & \\
\hline & $\mathrm{X} 8$ & 0.812 & 0.062 & 14.464 & & & \\
\hline & $\mathrm{X} 9$ & 0.854 & 0.063 & 15.746 & & & \\
\hline & $\mathrm{X} 10$ & 0.849 & - & - & & & \\
\hline \multirow{4}{*}{ Empowerment } & $\mathrm{X} 11$ & 0.865 & - & - & \multirow{4}{*}{0.926} & \multirow{4}{*}{0.919} & \multirow{4}{*}{0.739} \\
\hline & $\mathrm{X} 12$ & 0.839 & 0.054 & 17.547 & & & \\
\hline & $\mathrm{X} 13$ & 0.891 & 0.057 & 16.496 & & & \\
\hline & $\mathrm{X} 14$ & 0.843 & 0.054 & 18.703 & & & \\
\hline \multirow{3}{*}{$\begin{array}{c}\text { Service } \\
\text { innovation }\end{array}$} & $\mathrm{X} 15$ & 0.835 & - & - & \multirow{3}{*}{0.888} & \multirow{3}{*}{0.889} & \multirow{3}{*}{0.727} \\
\hline & $\mathrm{X} 16$ & 0.879 & 0.067 & 14.331 & & & \\
\hline & $\mathrm{X} 17$ & 0.844 & 0.065 & 15.371 & & & \\
\hline \multirow{3}{*}{$\begin{array}{l}\text { Competitive } \\
\text { advantage }\end{array}$} & X19 & 0.877 & - & - & \multirow{3}{*}{0.902} & \multirow{3}{*}{0.907} & \multirow{3}{*}{0.766} \\
\hline & $\mathrm{X} 20$ & 0.932 & 0.058 & 18.802 & & & \\
\hline & X21 & 0.812 & 0.066 & 14.967 & & & \\
\hline \multicolumn{8}{|c|}{$\begin{array}{c}\chi^{2} / \mathrm{df}=275.528(142), \mathrm{p}=0.000, \mathrm{CMIN} / \mathrm{DF}=1.940, \mathrm{GFI}=0.881, \mathrm{IFI}=0.962, \mathrm{TLI}=0.954, \\
\mathrm{CFI}=0.962, \mathrm{RMSEA}=0.075\end{array}$} \\
\hline
\end{tabular}

Note: Significant value at $* * \mathrm{p}=0.05, * * * \mathrm{p}=0.001$

Results of correlations analysis. Table 2 reported the results of correlations identified. The analysis verified discriminant validity, the square root of AVE of each factor was larger than the correlation coefficients between the factors (offdiagonal elements) (Fornell and Larcker, 1981). Therefore, the discriminant validity of all measurements used can be verified.

In detail, in the case of communication, the sub-dimension of internal marketing, there was a significant correlation of 0.150 with reward system, 0.165 with empowerment, 0.023 with service innovation and 0.072 with a competitive advantage. Further, there was a significant correlation between reward system and service innovation, between reward system and competitive advantage, as the value of 0.133 and 0.164 respectively. The correlation value between factors was 
significant as in Table 2 below.

Table. 2: Results of correlation analysis

\begin{tabular}{|c|c|c|c|c|c|}
\hline & CO & RS & EM & SI & CA \\
\hline Communication & $\mathbf{0 . 8 4 8}$ & & & & \\
\hline Reward system & $0.150^{*}$ & $\mathbf{0 . 8 5 7}$ & & & \\
\hline Empowerment & $0.165^{*}$ & $0.388^{* *}$ & $\mathbf{0 . 8 6 0}$ & & \\
\hline Service innovation & 0.023 & 0.133 & $0.256^{* *}$ & $\mathbf{0 . 8 5 3}$ & \\
\hline $\begin{array}{c}\text { Competitive } \\
\text { advantage }\end{array}$ & 0.072 & $0.164^{*}$ & $0.200^{* *}$ & $0.199 * *$ & $\mathbf{0 . 8 7 5}$ \\
\hline $\begin{array}{c}\text { CO: communication of IM, RS: Reward system of IM, EM; Empowerment, SI: Service } \\
\text { innovation, CA: Competitive advantage }\end{array}$ \\
\hline
\end{tabular}

Note: Significant value at $* * \mathrm{p}=0.05, * * * \mathrm{p}=0.001$

Results of path analysis. As shown in Table 3, all hypotheses in the path analysis are supported except for the relationship between service innovation and competitive advantage. That's, internal marketing is positively related to service innovation $(\beta=0.676, p=0.001)$ and competitive advantage $(\beta=-0.653, p=0.001)$, supporting $H 1$, and $H 3$, respectively. However, $H 2$ is not supported $(\beta=-0.100$, $\mathrm{p}=0.05)$. Based on these results, we suggested that $\mathrm{IM}$, which constructs 3 dimensions of communication, reward, and empowerment, influence service innovation. Service innovation mediates the effect relationship of internal marketing and competitive advantage.

Table. 3: Results of path analyses

\begin{tabular}{|c|c|c|c|c|c|c|}
\hline Hypothesis & Path & Estimates & SE & T-value & p-value & Results \\
\hline H1 & $\begin{array}{c}\text { Internal marketing } \\
\rightarrow \text { Service } \\
\text { innovation }\end{array}$ & 0.676 & 0.069 & $9.769^{* * *}$ & 0.000 & Supported \\
\hline H2 & $\begin{array}{c}\text { Service innovation } \\
\rightarrow \text { Competitive } \\
\text { advantage }\end{array}$ & 0.100 & 0.125 & 0.799 & 0.424 & $\begin{array}{c}\text { Unsupporte } \\
\mathrm{d}\end{array}$ \\
\hline H3 & $\begin{array}{c}\text { Internal marketing } \\
\rightarrow \text { Competitive } \\
\text { advantage }\end{array}$ & 0.653 & 0.111 & $5.869 * *$ & 0.000 & Supported \\
\hline \multicolumn{2}{|c|}{$\chi^{2} / \mathrm{df}=391497$ (202), p=0.000, CMIN/DF=1.938, GFI=0.856, IFI=0.952, TLI=0.945, } \\
\hline
\end{tabular}

Note: Significant value at $* * \mathrm{p}=0.05, * * * \mathrm{p}=0.001$ 


\section{Conclusion}

This paper examined to identify the internal marketing according to the three dimensions and the relationship between internal marketing and service innovation and hospital competitive advantage. The results showed that internal marketing has a positive effect on service innovation. Besides, internal marketing directly influences on competitive advantage. However, service innovation has no effect of competitive advantage.

To gain a competitive advantage in an organization comes from how to manage and construct communication, education \& training, reward, empowerment, etc. Therefore, through internal marketing activities such as having a good communication system with members in hospital organization, especially between leader and members, shifting empowerment to members, providing proper and fair reward system, organization attempted to be transformed with accepting service innovation. This kind of internal marketing policy increases employee satisfaction and loyalty. It, in turn, increase organization performance and decrease turnover rate. internal marketing is managing a company's human resources based on a marketing perspective (Frye et al., 2019; Kotler et al., 2017). As seen in their view, an organization treats its employees as internal customers as the role of organizational coaching. That's why, this paper showed that internal marketing is a vital factor to the organization's competitiveness as a view of organization coaching.

Consequently, we suggested that internal marketing as organization coaching has a positive effect on service innovation and then is the core factor to enhance the competitive advantage. As creating a sustainable competitive advantage may be the most essential goal of any organization including public institutes, CEOs or managers focus on how to suitably mix these sub-dimensions of internal marketing in the view of organizational coaching. Therefore, this paper suggests practical implications for public hospital managers, including private hospital managers, from a management perspective.

For further research, it is meaningful that we study on regarding internal marketing as a view of organization coaching more.

\section{References}

Bang, W. S. (2017). Creating Competitive Advantage through Internal Marketing in the Medical Industry, Doctoral paper of Gyeongsang National University.

Bang, W. S., Chung, K. H. \& Shin, J. I. (2017). Enhancing Internal Customer Loyalty through Internal Marketing in Public Medical Organizations. The Journal of Internet Electronic Commerce Research, 17(5), 153-166.

Boudreau, M. C., Gefen, D. \& Straub, D. W. (2001). Validation in information systems research: A state-of-the-art assessment. MIS quarterly, 1-16. 
Chen, S., Duan, Y., Edwards, J. S. \& Lehaney, B. (2006). Toward understanding inter-organizational knowledge transfer needs in SMEs: insight from a UK investigation. Journal of knowledge management, 10(3), 6-23.

Choi, S. Y. (2018). The Effects of Perceived Organizational Support and Job Efficacy on Social Workers' Job Performance. Asia-pacific Journal of Convergent Research Interchange, SoCoRI, ISSN: 2508-9080 (Print); 2671-5325 (Online), 4(3), 43-52

Distanont, A. \& Khongmalai, O. (2018). The role of innovation in creating a competitive advantage. Kasetsart Journal of Social Sciences.

Fornell, C. \& Larcker, D. F. (1981). Structural equation models with unobservable variables and measurement error: Algebra and statistics.

Frye, W. D., Kang, S., Huh, C. \& Lee, M. J. M. (2019). What factors influence Generation Y's employee retention in the hospitality industry? An internal marketing approach. International Journal of Hospitality Management, 102-352.

Hsieh, J. K., Chiu, H. C., Wei, C. P., Rebecca Yen, H. \& Cheng, Y. C. (2013). A practical perspective on the classification of service innovations. Journal of Services Marketing, 27(5), 371-384.

Ieong, C. Y. \& Lam, D. (2016). Role of internal marketing on employees' perceived job performance in an Asian integrated resort. Journal of Hospitality Marketing \& Management, 25(5), 589-612.

Jung, G. J., Hwang, H. J. \& Song, I. A. (2015). Impact of Internal Marketing Factors on Technological Innovation and Perceived Service Quality in Telecommunications. Journal of Distribution Science, 13(6), 87-96.

Kim, N. G. (2018). Knowledge Information Firm's Corporate Divestitures. Asiapacific Journal of Convergent Research Interchange, SoCoRI, ISSN: 2508-9080 (Print); 2671-5325 (Online), 4(1), 63-70.

Kotler, P., Bowen, J. T., Makens, J. C. \& Baloglu, S. (2017). Marketing for Hospitality and Tourism, 7th ed. Prentice Hall, Upper Saddle River, NJ.

Murphy, K. R. \& Davidshofer, C. O. (1988). Psychological testing: Principles and applications. Engle-wood Cliffs, NJ: Prentice-Hall.

Nam, W. J. \& Lee, C. S. (2009). The Mediating Effect of Management Strategy on the Relationship of Internal Marketing and Performance of Hotel Corporations. Korean Journal of Hotel Administration, 18(3).

Nunnally, I. C. \& Bernstin, I. H. (1994). Psychometric theory (3rd ed.). NY: McGraw-Hill. 
Papadas, K. K., Avlonitis, G. J., Carrigan, M. \& Piha, L. (2018). The interplay of strategic and internal Green marketing orientation on competitive advantage. Journal of Business Research.

Porter, M. E. \& Millar, V. E. (1985). How information gives you competitive advantage.

Shim W. G. \& Choi, H. G. (2014). A Study on the Structural Relationships between Internal Marketing and Organizational Performance in University. Society Science Research, 38(2).

Skalen, P., Gummerus, J., Von Khoskull, C. \& Magnusson. P. R. (2015). "Value propositions and service innovation: a service-dominant logic study,". Journal of the Academy of Marketing Science, 43(2), 137-158.

Wei Chong C., Choy Chong, S. \& Chew Gan, G. (2011). Inter-organizational knowledge transfer needs among small and medium enterprises. Library Review, 60(1), 37-52.

Yeum, M. S. \& Wee, K. H. (2019). The Effect of Internal Marketing on Competitive Advantage as Organizational Coaching - Mediating Effect of Service Innovation. International Journal of Business Policy and Strategy Management, 6(1), 7-12. 